\title{
RECIDIVOUS CANINE DEMODICOSIS SECONDARY TO HYPOTHYRODISM
}

SINCERO, P.C. ${ }^{1}$; FOGAÇA, R. ${ }^{2}$; FERRARI, M.V ${ }^{3}$; BRITO, H.F.V. ${ }^{1}$; FRANCO, M.B. ${ }^{1}$; KASECKER, G.G. ${ }^{1}$; PERRONI, M.A. ${ }^{1}$; TRANQUILIM, M.V. ${ }^{1}$; WERNER, J. $^{1}$

${ }^{1}$ Mestrandos, Curso de Pós-Graduação em Ciências Veterinárias, UFPR;

${ }^{2}$ Departamento de Fisiologia-UFPR;

${ }^{3}$ Departamento de Medicina Veterinária-UFPR.

Demodicosis is an inflammatory disease of parasitic origin that affects skin. It is characterized by the presence of a larger number of demodecic acari than normal. Imunossupression disorders such hypothyrodism can increase such susceptibility. A eight months old male Rottweiller dog was received at the Small Animals Medical Clinical Service of the Veterinary Hospital of UFPR displaying alopecy, moderate pruritus and widespread pyodermatitis. A deep scrape of skin was analyzed by microscope and revealed a great quantity of acari (Demodex sp.). This animal was medicate with ivermectine $(0,04 \mathrm{ml} / \mathrm{kg})$ subcutaneously, once a week, up to four administrations. The dog also received antibiotictherapy, using enrofloxacine $(5 \mathrm{mg} / \mathrm{kg})$ twice a day, for ten days to treat secondary pyodermatitis. Four months later, the patient returned displaying the same clinical signs, associated to alopecy, symmetrically distributed and bilaterally on the back. Pododermatitis was also observed. It was then performed a new exam of a skin scrape which resulted positive again. Then, it was decided to carry on a mensuration of thyroid hormone (T4) and the result was compatible with hypothyrodism. The patient was treated for demodicosis by oral administration of ivermectine $(0,08 \mathrm{ml} / \mathrm{kg})$ once a day, during 30 days. Besides this, the dog also received a hormonal supplementation with 0,02 $\mathrm{mg} / \mathrm{kg}$ levotyroxine (T4), twice a day with a controll of the clinical signs. This report aims to alert the clinics that animals with chronic or recidivous demodicosis, usually presents a primary affection typical to the process. Hypothyrodism is an important and common hormonal disorder that was currently associated to demodicosis.

Key Words: demodicosis, hypothyrodism, Rotweiller dog. 